\title{
Assessment of Andean lupin (Lupinus mutabilis) Genotypes for Improved Frost Tolerance
}

\author{
Danut Petru Simioniuc ${ }^{1}$ (), Violeta Simioniuc ${ }^{1}$, Denis Topa ${ }^{2}$, Merlijn van den Berg ${ }^{3}$, Udo Prins ${ }^{3}$, \\ Penelope J. Bebeli ${ }^{4}$ and Iulian Gabur ${ }^{1, *}$ \\ 1 Department of Plant Sciences, "Ion Ionescu de la Brad" University of Agricultural Sciences and Veterinary \\ Medicine, 700490 Iasi, Romania; simion@uaiasi.ro (D.P.S.); vsimion@uaiasi.ro (V.S.) \\ 2 Department of Pedotechnics, "Ion Ionescu de la Brad" University of Agricultural Sciences and Veterinary \\ Medicine, 700490 Iasi, Romania; topadennis@uaiasi.ro \\ 3 Department of Breeding \& Innovative Production Chains, Louis Bolk Institute, \\ 3981 AJ Bunnik, The Netherlands; M.vandenBerg@Louisbolk.nl (M.v.d.B.); U.Prins@Louisbolk.nl (U.P.) \\ 4 Laboratory of Plant Breeding and Biometry, Department of Crop Science, Agricultural University of Athens, \\ 11855 Athens, Greece; bebeli@aua.gr \\ * Correspondence: gaburi@uaiasi.ro
}

Citation: Simioniuc, D.P.; Simioniuc, V.; Topa, D.; van den Berg, M.; Prins, U.; Bebeli, P.J.; Gabur, I. Assessment of Andean lupin (Lupinus mutabilis) Genotypes for Improved Frost Tolerance. Agriculture 2021, 11, 155. https://doi.org/10.3390/

agriculture11020155

Academic Editor: Gianluca Caruso; László Baranyai and Vasile Stoleru

Received: 27 January 2021

Accepted: 9 February 2021

Published: 13 February 2021

Publisher's Note: MDPI stays neutral with regard to jurisdictional claims in published maps and institutional affiliations.

Copyright: (c) 2021 by the authors. Licensee MDPI, Basel, Switzerland. This article is an open access article distributed under the terms and conditions of the Creative Commons Attribution (CC BY) license (https:/ / creativecommons.org/licenses/by/ $4.0 /)$.
Abstract: Spring frost poses a challenge for all major crops and, in the case of Lupinus mutabilis (Andean lupin) can cause severe damage or even total loss of the crop. Within the LIBBIO project consortium, we conducted a series of experiments in order to develop a suitable protocol for screening lupin germplasm under frost-simulation conditions. Four lupin accessions, one Lupinus albus and three Andean lupins were used in the experiments (L. albus Mihai, L. mutabilis LIB 220, LIB 221, LIB 222). Seedlings at four developmental stages were challenged with five different levels of 'frost' stress from low $\left(-2{ }^{\circ} \mathrm{C}\right)$ to high $\left(-10^{\circ} \mathrm{C}\right)$. Notably, young seedling (cotyledons just breaking through the soil surface) showed little evidence of frost damage for temperatures down to $-6{ }^{\circ} \mathrm{C}$. At $-8{ }^{\circ} \mathrm{C}$, however, damage was evident, suggesting a cold tolerance threshold occurs at this temperature. Interestingly, for later developmental stages, when the first and second leaves were visible, notable differences were observed starting at $-6{ }^{\circ} \mathrm{C}$. The results indicate that the plant growth stage is an important parameter when screening for frost tolerance in germplasm. Overall, by identifying Andean lupin genotypes adapted to high abiotic stress factors, farmers will be able to use it as a reference crop with potentially a commercial interest from the food sector, or cosmetics, and biofuel industries.

Keywords: Andean lupin; L. albus; L. mutabilis; abiotic stress; frost tolerance

\section{Introduction}

In recent years, the agricultural sector has faced a series of major challenges like the need for safe and clean food products, environmentally sustainable production and constant changes in consumer preferences. World population continues to grow and will reach a predicted 9 billion by 2050. At the same time, many scientists believe that it will be a challenge to feed such an expanding population, and new higher yielding, more resistant crops will be required. Additionally, a more equitable distribution of the existing food products could represent a pertinent solution to many food shortage problems we are facing today. Extensive agriculture practices may contribute to the loss of biodiversity and a disproportionate use of land and fresh water resources. Increased demand for protein-rich diets, especially of animal origin, contributed to the decline in soil fertility and is considered to be a major factor that is enhancing climate change in many regions. A solution for this could be to increase the cultivation of protein-rich crops and the use of plant proteins in human diets. Lupinus mutabilis is a species that produces high protein content seeds and might represent a strong alternative to already well-established protein species cultivated in the entire world [1]. 
Through its policies the European Union stimulated growers to increase the area for cultivating protein crops and to make significant changes in the management practices, towards a more sustainable agricultural system. Among protein-rich plant sources, leguminous plants are known for their beneficial effects, greater adaptation to poor soils, and the ability to fix atmospheric nitrogen [2]. Among legumes, the genus Lupinus includes more than 300 species and is described as a high-quality protein crop, with tolerance to soils with poor soil fertility [3]. Lupinus mutabilis (Andean lupin) is a crop species indigenous to the Andes in South America but evidence of its cultivation in other regions of South America was found. Lucas et al. [4] described L. mutabilis as a very promising alternative crop with increased dietary benefits compared to soya bean, a high grain quality, and improved adaptation to poor soils, high altitudes, and low input farming systems. Its suitability for cultivation in temperate climates, and high protein and oil grain content are among the characteristics that make Andean lupin a promising alternative to current protein crops [5].

Adaptation of L. mutabilis to the temperate environment is a major breeding challenge due to the major environmental differences between various cultivation areas in Europe. Andean lupin, when cultivated in temperate climate conditions shows long maturation periods, flower and pod abortion, and non-shattering pods [6]. A very low resistance to frost limits the potential cultivation areas of Andean lupin in Europe to Mediterranean climates and the spring season in northern countries [5]. Moreover, dry conditions during flowering might stimulate Andean lupin to early maturation and cause considerable biomass and seed yield losses [7]. Studies on vernalization effects on flowering time reported that cold treatments at $6{ }^{\circ} \mathrm{C}$ to a few weeks can reduce the overall time gap between early and late flowering genotypes to few weeks [8]. Adaptation to various environmental conditions is known to be influenced by the capacity of genotypes to respond to photoperiods. Jacobsen and Mujica [9] consider L. mutabilis to be sensitive to day length, such that under short days, the crop accumulates compounds in the grain more efficiently. This suggests that selection of germplasm with sensitivity to day length should be based on geographical parameters and the climate of an arable area. Future breeding efforts should be focused on the identification of genotypes with early maturation periods and high tolerance to frost and drought, while conserving the high protein and oil content in seeds and increased yields.

A limited number of studies are published on Andean lupin performance in European countries and especially on how frost tolerance impacts the different plant development phases. This study describes a new protocol for frost-simulated tolerance tests of $L$. mutabilis accessions. To determine frost tolerance levels that occur in Andean lupin, a series of climate chamber experiments were performed. Four important plant development phases were tested in frost-simulation conditions using temperatures ranging from $+5{ }^{\circ} \mathrm{C}$ to $-10^{\circ} \mathrm{C}$. Contrasting genotypes were analyzed and the effects of frost on the vigor of the phenotypes were observed.

\section{Materials and Methods}

\subsection{Plant Material}

Four accessions of Lupinus were used-one L. albus (cultivar Mihai) and three L. mutabilis (LIB 220, LIB 221 and LIB 222). The commercial L. albus cv. Mihai was previously characterized as a moderate frost tolerant accession. LIB 220, LIB 221, and LIB 222 were described to exhibit indeterminate growth habits and low frost tolerance. Seed germination was conducted on filter paper after disinfection for a few minutes with a $20 \%$ hypochlorite solution and incubation at room temperature (approximately $24^{\circ} \mathrm{C}$ ). Measurements of the seedling survival rate were recorded and used in further analysis. Germinated seeds were transplanted into the greenhouse using a substrate of peat:perlite (2:1) for $48 \mathrm{~h}$ and then transferred to the climate chamber. 


\subsection{Experimental Design of Artificial-Frost Tolerance Investigations}

Deep planter boxes were filled to $2 / 3$ capacity with commercial compost at room temperature and watered to $70 \%$ water holding capacity (WHC). WHC was determined by initially weighing a volume of dry soil, adding water to full capacity, draining off excess water and re-measuring the soil. Formula (1) was used to calculate the volume necessary for $70 \%$ WHC:

$$
\begin{gathered}
\text { WHC }(\%)=\frac{\mathrm{SW}_{100}-\mathrm{SW}_{0}}{\mathrm{~W}} \times 100 \\
\mathrm{SW}_{100} \text { - soil weight at } 100 \% \mathrm{WHC} \\
\mathrm{SW}_{0} \text {-dry soil weight }(0 \% \mathrm{WHC}) \\
\mathrm{W} \text { - water added to reach } 100 \% \mathrm{WHC}
\end{gathered}
$$

For each accession, a total number of 300 seeds were sown. Seeds were planted in potting soil, at a planting distance of $5 \mathrm{~cm}$ from each other and covered with $4 \mathrm{~cm}$, with potting soil in 30 containers. They were germinated at $15^{\circ} \mathrm{C}$ and a light regime of $16 \mathrm{~h}$ light $/ 8 \mathrm{~h}$ dark for the first $48 \mathrm{~h}$. The plants were transferred afterwards to $5{ }^{\circ} \mathrm{C}$ for $24 \mathrm{~h}$ for hardening. After hardening, 6 containers with 10 plants/accession each were exposed to each simulated frost level for $8 \mathrm{~h}$, according to the test temperature selected. This generated 6 technical and 10 biological repetitions for each genotype. The seedlings were exposed to five levels of simulated frost conditions: $-2{ }^{\circ} \mathrm{C},-4{ }^{\circ} \mathrm{C},-6{ }^{\circ} \mathrm{C}-8{ }^{\circ} \mathrm{C}$, or $-10{ }^{\circ} \mathrm{C}$ (Table 1). Afterwards, the seedlings were transferred to $15^{\circ} \mathrm{C}$ for $72 \mathrm{~h}$ to recover. Plants were scored for frost tolerance using a $0-1$ scale, where 0 denotes healthy plants and 1 corresponds to severe damage or dead plants. This binary scoring scale results were used for

\begin{tabular}{|c|c|}
\hline Plant Developmental Phase & Test Temperature (Day/Night) \\
\hline Phase $1-$ Cotyledons at breaking soil surface & $\begin{array}{c}-2{ }^{\circ} \mathrm{C} \\
-4{ }^{\circ} \mathrm{C} \\
-6{ }^{\circ} \mathrm{C} \\
-8{ }^{\circ} \mathrm{C} \\
-10^{\circ} \mathrm{C} \\
5{ }^{\circ} \mathrm{C} \text { control }\end{array}$ \\
\hline Phase 2-Cotyledons fully above the soil & $\begin{array}{c}-2{ }^{\circ} \mathrm{C} \\
-4{ }^{\circ} \mathrm{C} \\
-6{ }^{\circ} \mathrm{C} \\
-8{ }^{\circ} \mathrm{C} \\
-10^{\circ} \mathrm{C} \\
5{ }^{\circ} \mathrm{C} \text { control }\end{array}$ \\
\hline $\begin{array}{l}\text { Phase 3-First leaves visible and erect but } \\
\text { folded }\end{array}$ & $\begin{array}{c}-2{ }^{\circ} \mathrm{C} \\
-4{ }^{\circ} \mathrm{C} \\
-6{ }^{\circ} \mathrm{C} \\
-8{ }^{\circ} \mathrm{C} \\
-10^{\circ} \mathrm{C} \\
5{ }^{\circ} \mathrm{C} \text { control }\end{array}$ \\
\hline $\begin{array}{c}\text { Phase } 4-\text { First and second leaves have } \\
\text { unfolded }\end{array}$ & $\begin{array}{c}-2{ }^{\circ} \mathrm{C} \\
-4{ }^{\circ} \mathrm{C} \\
-6{ }^{\circ} \mathrm{C} \\
-8{ }^{\circ} \mathrm{C} \\
-10^{\circ} \mathrm{C} \\
5{ }^{\circ} \mathrm{C} \text { control }\end{array}$ \\
\hline
\end{tabular}
further analysis.

Table 1. Plant developmental phases and testing temperatures for frost tolerance under artificial conditions in the greenhouse. Germination of seedlings was performed at $15^{\circ} \mathrm{C}$. 
Plants were scored at four developmental stages (Figure 1 and Table 1). The developmental phases were-phase 1 when cotyledons were breaking through the soil surface; phase 2 with the cotyledons fully above the soil, phase 3 when first leaves were visible but still folded; and phase 4 when the first and second leaves had unfolded (Figure 1).

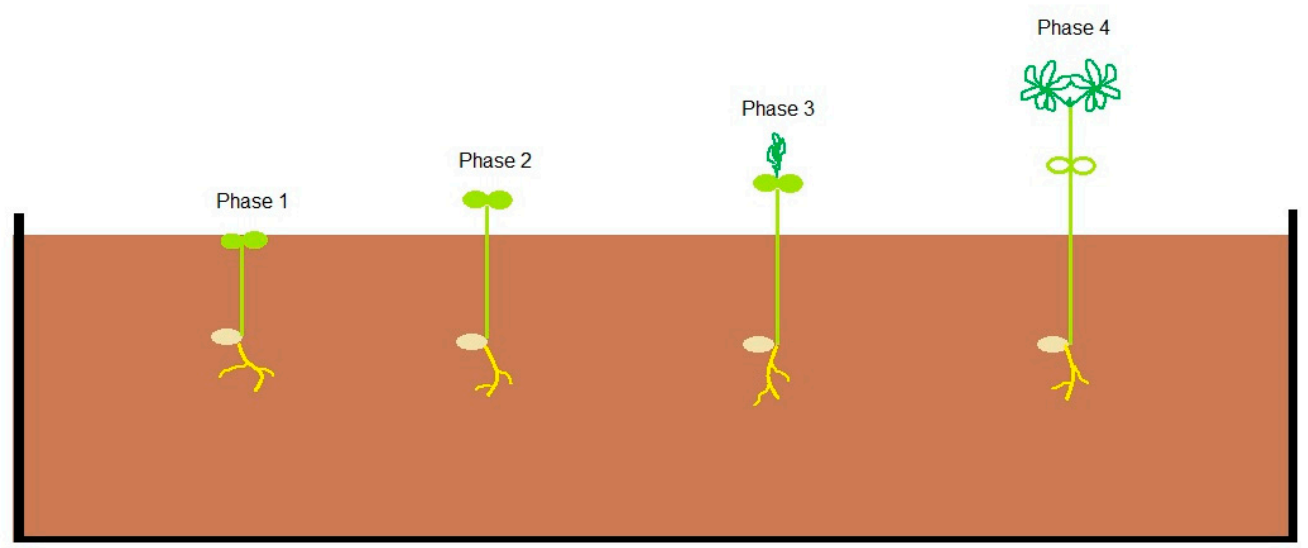

Figure 1. General plant phases used during the artificial simulated frost tolerance tests on the L. albus commercial cultivar Mihai and L. mutabilis accessions LIB 220, LIB 221, and LIB 222.

\subsection{Statistical Analysis}

Statistical analysis was performed simultaneously for the two consecutive experimental lots-lot one contained seeds investigated during phases 1 and 2, and the second lot contained plants investigated during phases 3 and 4 . As a result, this analysis allowed for better interpretation of the results. Recorded data were subjected to a normality test and homoscedasticity of each of the two experimental lots was checked. Analysis of variance (ANOVA) was applied for the temperature and developmental phases studied for each experimental lot, followed by Tukey's (honestly significant difference, HSD) $(p<0.05)$ means comparison method, using RStudio and the statistical package tools "aov" and "TukeyHSD" [10]. Figures and column charts were obtained using R studio, "boxplots", or Microsoft Office Excel/PowerPoint.

\section{Results and Discussion}

Most Andean lupin accessions, due to their adaptation to South American agricultural regions, are expected to inherit a low tolerance to spring frost. To date, no protocol is available for the large-scale screening of lupin germplasm under frost conditions. Within the LIBBIO project consortium, we conducted a series of investigations in order to develop a suitable protocol for screening lupin germplasm under artificial frost-simulation conditions. Four lupin accessions, one L. albus and three L. mutabilis (Andean lupin) were used in the tests (L. albus Mihai, LIB 220, LIB 221, and LIB 222). Various seedling development stages were investigated under five temperatures, from $-2{ }^{\circ} \mathrm{C}$ to $-10{ }^{\circ} \mathrm{C}$, indicative of low and high frost stress conditions (Figure 2). 


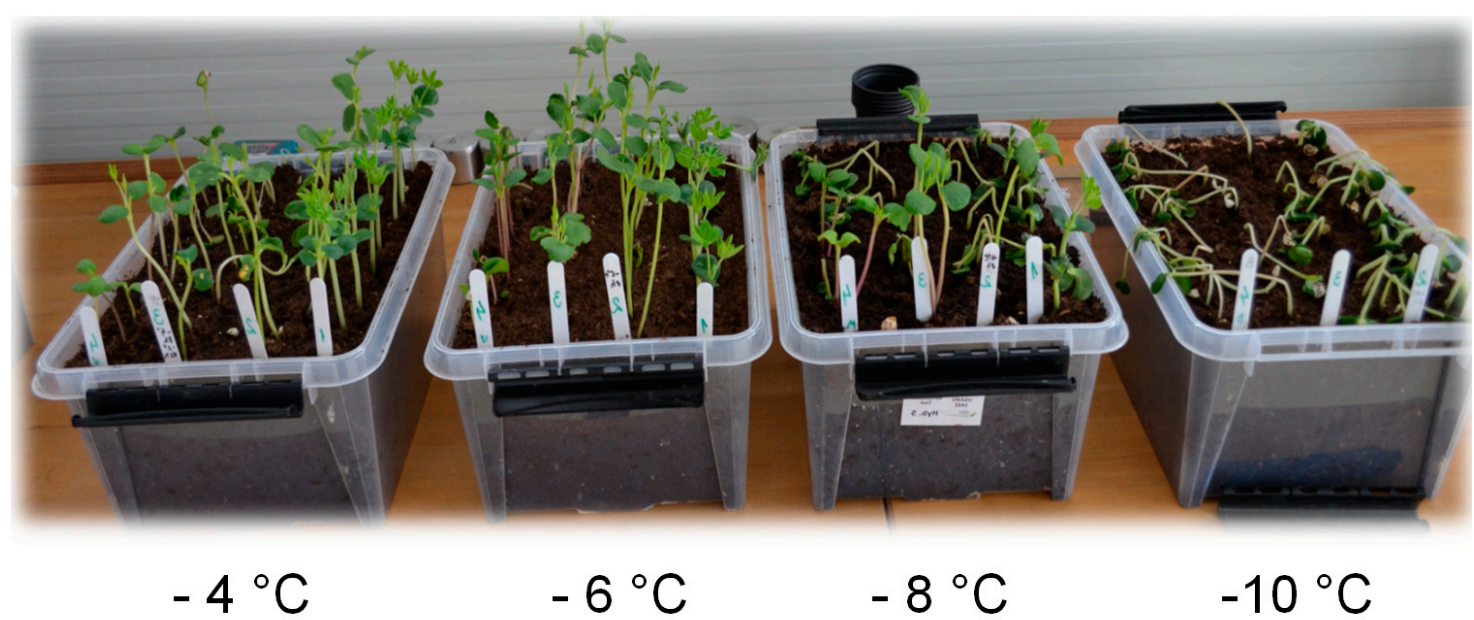

Figure 2. Seedlings test under artificial-controlled conditions from low $\left(-2{ }^{\circ} \mathrm{C}\right)$ to high $\left(-10^{\circ} \mathrm{C}\right)$ frost stress of four lupin accessions, L. albus cv. Mihai, L. mutabilis LIB 220, LIB 221 and LIB 222. Each container had 10 seedlings/accession, in total 40 seedling. Scoring was done at the developmental phase 4.

\subsection{Artificial-Frost Tolerance Assessment of Andean lupin Genotypes}

Generally, L. mutabilis seedling tolerance decreased with a decline in temperature. For phase 1 and phase 2, no differences were observed for temperatures down to $-6{ }^{\circ} \mathrm{C}$ (Figure 3). However, plants started to be affected from $-8^{\circ} \mathrm{C}$, suggesting that a specific cold tolerance threshold lies between -6 and $-8^{\circ} \mathrm{C}$ for phase 1 and 2 seedlings.

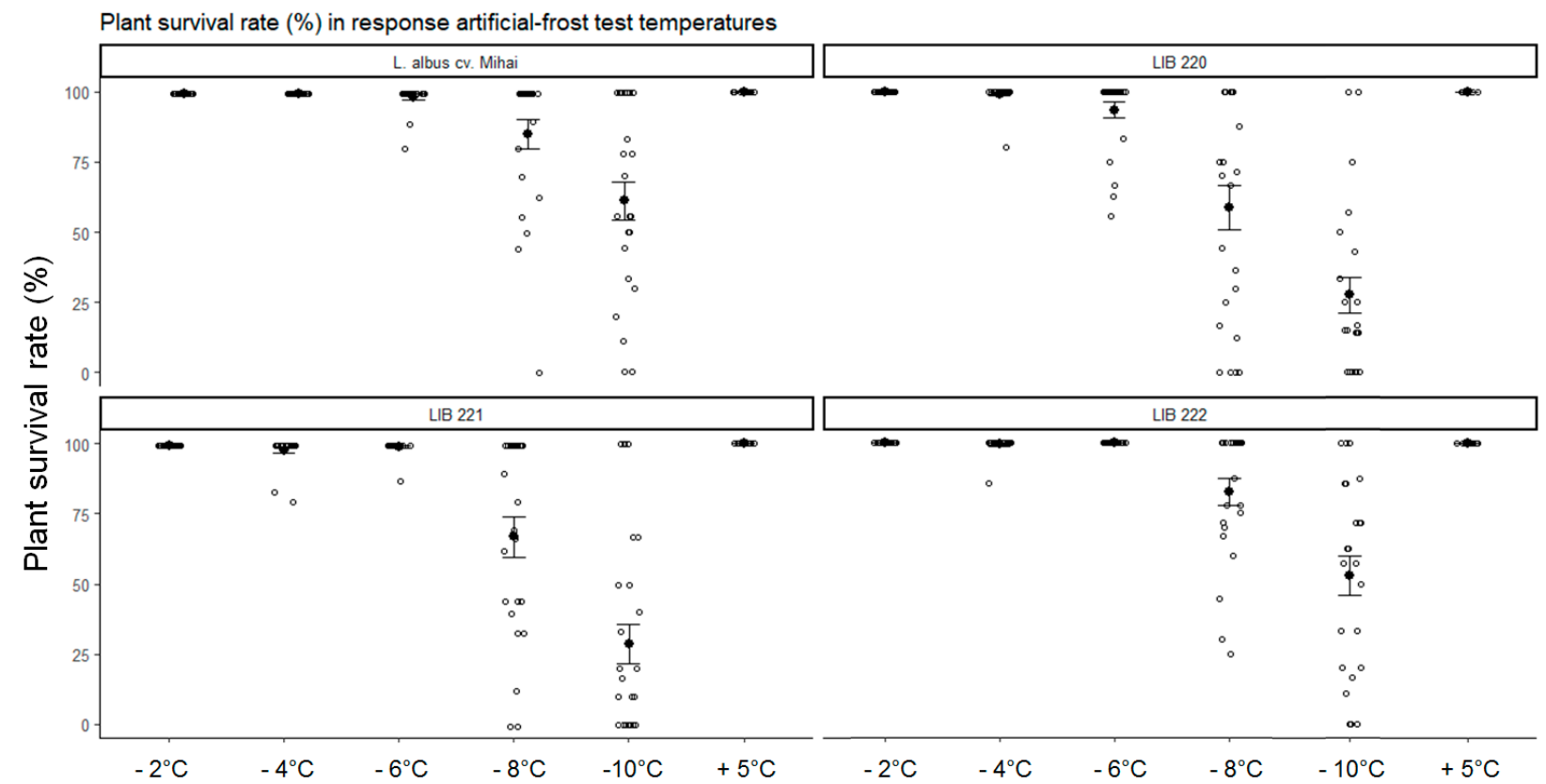

Figure 3. Assessment of four accessions, L. albus cv. Mihai and L. mutabilis LIB 220, LIB 221, and LIB 222 plant survival rate, in percentage, in response to artificial-frost test temperatures ranging from low $\left(-2{ }^{\circ} \mathrm{C}\right)$ to high $\left(-10^{\circ} \mathrm{C}\right)$ frost stress and with control samples at $\left(+5^{\circ} \mathrm{C}\right)$. Each dot represents the mean survival rate $(\%)$ of the 10 biological replicates, from one of the six containers, per genotype $x$ temperature comparison, across all developmental phases.

Interestingly, for seedlings at phases 3 and 4, differences in stress damage were already evident at $-6{ }^{\circ} \mathrm{C}$ (Figure 3). Frost of $-8^{\circ} \mathrm{C}$ resulted in differences in seedling damage relative to the other temperatures, while $-10^{\circ} \mathrm{C}$ resulted in the highest overall seedling damage (Table S1). 


\subsection{Plant Developmental Phases Influence Frost Tolerance of Andean lupin}

For phase 1 and 2 L. albus cv. Mihai and LIB221 were most tolerant. Notably, in phase 3 and 4, apart from L. albus cv. Mihai, LIB222 outperformed the other genotypes (Figure 4). This indicates that the tolerance threshold has a genetic component. Interestingly LIB222 is a genotype that is characterized by a higher level of anthocyanin in the tissue, mainly visible as a purple colored stem and darker flower color. Since anthocyanin is induced in some crop species when exposed to the cold [11], this might provide a clue to LIB222 frost tolerance compared to the other Andean lupin accessions.

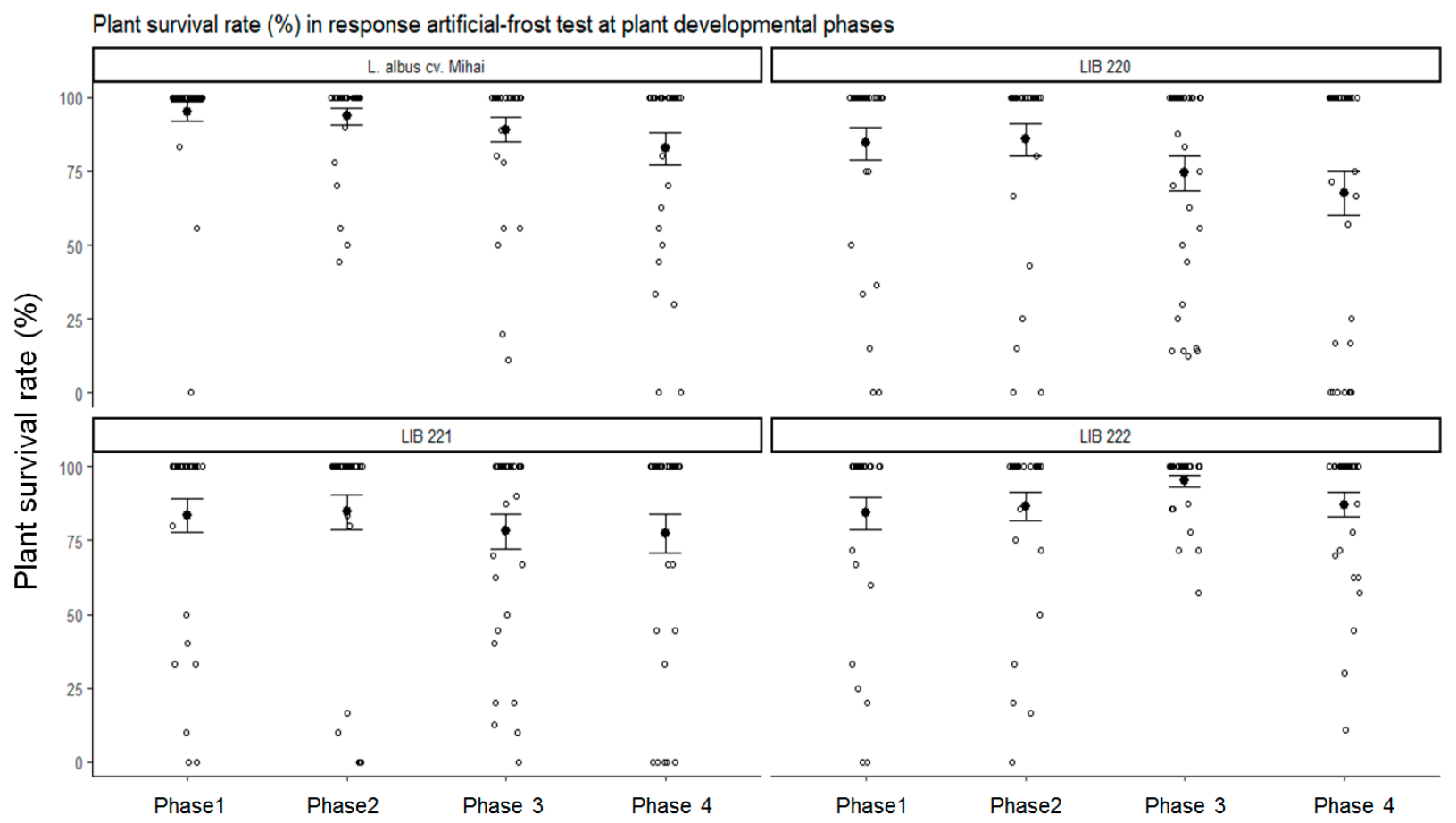

Figure 4. Evaluation of plant developmental phases with regard to accession and impact frost stress on seedlings. Phase 1-cotyledons at breaking soil surface phase (cotyledon); Phase 2-cotyledons fully above the soil; Phase 3-first leaves visible and erect but folded; and Phase 4-first and second leaves have unfolded. Each dot represents the mean survival rate $(\%)$ of the 10 biological replicates, from one of the six containers, per genotype $x$ developmental phases comparison across all test temperatures.

Andean lupin seedlings are known to show some frost tolerance during previous experiments, and generally, for all four developmental phases, the lower the temperature the greater the frost damage. In the initial tests no differences were observed for temperatures down to $-6^{\circ} \mathrm{C}$, for seedlings at cotyledon Phase 1 . However, frost treatments started to affect the emerged plants at $-8{ }^{\circ} \mathrm{C}$, suggesting that this could be the Andean lupin frost tolerance level for early developmental phases. Interestingly, for later development stages, as first and second leaves were visible, notable differences were observed starting with $-6{ }^{\circ} \mathrm{C}$. Frost treatments at $-8{ }^{\circ} \mathrm{C}$ resulted in differences in seedling damage, relative to the other temperatures, while at $-10^{\circ} \mathrm{C}$ the highest overall seedling damage was observed. Differences between genotypes were observed, especially higher frost tolerance for $L$. albus (Mihai) and LIB 222 (Figure 5). 


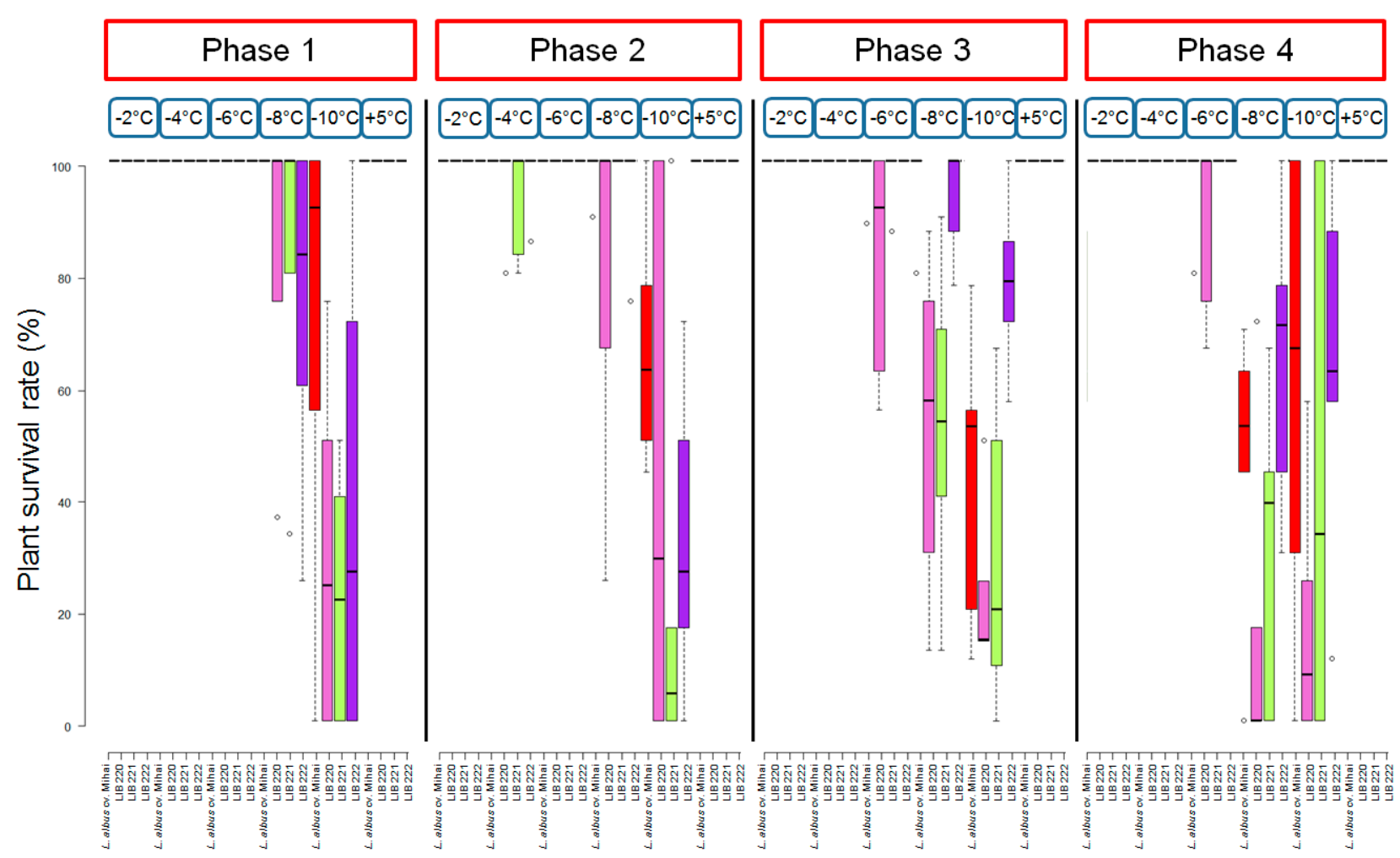

Figure 5. Assessment of Andean lupin accessions under the influence of artificial-frost test temperatures ranging from low $\left(-2{ }^{\circ} \mathrm{C}\right)$ to high $\left(-10^{\circ} \mathrm{C}\right)$ frost stress and with control samples at $\left(+5^{\circ} \mathrm{C}\right)$ and plant developmental phases, from Phase 1 to Phase 4. Each genotype is color coded: L. albus cv. Mihai (red), LIB 220 (orchid), LIB 221 (olive-green), and LIB 222 (purple).

The results indicate that the plant growth stage is an important parameter when screening for frost tolerance in germplasm. Plants are generally more susceptible to frost at the cotyledon stage. We used seedlings at development stages and exposed them to severe cold stress in order to identify the minimal resistance threshold that Andean lupin has in response to different freezing temperatures. Overall, identifying Andean lupin genotypes adapted to high abiotic stress factors might allow the cultivation of lupin over a greater geographic range by farmers.

\subsection{Investigation of Significance among Development Phases, Temperatures, and Accessions}

Significant differences were observed between all investigated parameters such as the four plant developmental phases, the stress tolerance test temperatures that varied from low $\left(-2{ }^{\circ} \mathrm{C}\right)$ to high $\left(-10^{\circ} \mathrm{C}\right)$, and most importantly between the four investigated accessions (Table 2). Pairwise comparisons of all investigated parameters showed a large number of strongly significant difference, especially among very high stress temperatures and control samples (Tables S1 and S2). 
Table 2. Multi-factor analysis of variance of four lupin accession, one L. albus and three L. mutabilis, under the influence of developmental phase, temperature, and their interaction.

\begin{tabular}{|c|c|c|c|c|c|c|}
\hline & Df & Sum Sq & Mean Sq & F Value & $\begin{array}{c}p \text {-Value } \\
(>\mathrm{F})\end{array}$ & Significance \\
\hline Phase & 3 & 7024 & 2341 & 7229 & $<0.0001$ & $* * *$ \\
\hline Temperature & 4 & 239224 & 59806 & 184,647 & $<0.0001$ & $* * *$ \\
\hline Genotype & 3 & 14607 & 4869 & 15,033 & $<0.0001$ & $* * *$ \\
\hline $\begin{array}{c}\text { Phase } \times \\
\text { Temperature }\end{array}$ & 12 & 35840 & 2987 & 9221 & $<0.0001$ & $* * *$ \\
\hline $\begin{array}{l}\text { Phase } \times \\
\text { Genotype }\end{array}$ & 9 & 8418 & 935 & 2888 & 0.00256 & $* *$ \\
\hline $\begin{array}{c}\text { Temperature } \times \\
\text { Genotype } \\
\text { Phase } x\end{array}$ & 12 & 18455 & 1538 & 4748 & $<0.0001$ & $* * *$ \\
\hline $\begin{array}{c}\text { Temperature } \times \\
\text { Genotype }\end{array}$ & 36 & 18356 & 510 & 1574 & $<0.0001$ & * \\
\hline Residuals & 400 & 129557 & 324 & & & \\
\hline
\end{tabular}

According to pairwise comparisons among the developmental stages, phase 4 is statistically different from phase 1 and phase 2 . No statistical differences were found among test temperatures $+5{ }^{\circ} \mathrm{C},-2{ }^{\circ} \mathrm{C},-4{ }^{\circ} \mathrm{C}$, while for all other pairwise comparisons strong differences were observed. Regarding the accessions, there were statistical differences among L. albus cv Mihai, LIB 220 and LIB 221, while LIB 220 and LIB 221 did not present any statistically significant differences (Table S2).

Frost tolerance of various lupin accessions was evaluated under low $\left(-2{ }^{\circ} \mathrm{C}\right)$ to very high $\left(-10{ }^{\circ} \mathrm{C}\right)$ temperature stress and showed overall differences with regard to plant development phase and genotype. Despite the fact that limited reports on lupin frost tolerance exists in the literature, it is known that vernalization is necessary for accessions with late flowering genotype growth [8]. Andean lupin plants showed variation in height of the main stem, number of main stem leaves, and seed yield, under the influence of temperature in European environmental conditions [12]. A short cold treatment in later developmental stages stimulates the initiation of meristems, the start of the flowering and biomass accumulation [8]. Identification of genotypes that are able to withstand early spring frost specifically for Northern European countries and which have increased drought tolerance might encourage the widespread cultivation of lupin in the EU [5]. Moreover, severe heat stress during late spring and summer might inhibit pod and seed production on higher branches [13], thus limiting more than $95 \%$ of L. mutabilis seed production on the main inflorescence [14].

Andean lupin accessions with long life cycles and indeterminate growth are very susceptible to adverse climatic conditions that might cause reduced pod production and low seed yields [12] and restrict biomass accumulation due to drought [7]. However, in Greece, indeterminate growth accessions produced higher yields, around $1.5 \mathrm{t} / \mathrm{ha}$ [13]. Some L. mutabilis accessions evaluated in Ecuador reached their production potential in good climatic conditions, but under severe abiotic and biotic stresses, lupin might yield very low seed quantities, as low as $130 \mathrm{~kg} / \mathrm{ha}$ [15]. Moreover, soils with high $\mathrm{pH}$ values that are rich in calcium carbonate are known to generate low yields for Andean lupin accessions [16,17]. Yields might also be positively influenced by a denser seed sowing for semi-determinate growing genotypes, as described by Pszczółkowska et al. [18]. Accessions investigated in this study are from the indeterminate group with a long-life cycle, namely LIB221 and LIB222, while LIB220 and L. albus cv. Mihai belong to the semideterminate growth group. Breeding of lupin cultivars with high yields is dependent on the identification of accessions with an appropriate time interval needed from sowing to flowering and maturity [19]. 
Artificially induced frost stress significantly affected the tolerance levels of the selected accessions, especially under high stress levels, regardless of plant developmental phase. Temperature was the main factor that affected the tolerance of accessions, whereas some statistical differences were recorded for the developmental phases. Similarly, previous evaluations of lupin genotypes, done in the mid-1930s, in Germany, showed that low temperatures affected L. albus, L. mutabilis, L. angustifolius, and L. luteus in a distinctive manner [20]. Therefore, accessions and temperature responses should be assessed, in more detail, for each plant developmental stage. Further investigations are needed to identify Andean lupin accessions with high frost tolerance and improved yield capacity.

\section{Conclusions}

In most European countries, spring frost represents an important impediment for the agricultural sector, causing severe or total yield loses. Lupinus mutabilis (Andean lupin) seedlings are susceptible to this stress and the identification of genotypes with increased frost tolerance might be a viable solution for the widespread cultivation of this crop in the EU. A new protocol was developed for the investigation of the effect of frost stress by artificial frost-simulation conditions of several Andean lupin accessions. Four seedling developmental phases were investigated under five test temperatures, from low $\left(-2{ }^{\circ} \mathrm{C}\right)$ to high $\left(-10^{\circ} \mathrm{C}\right)$ frost stress. The four accessions used in the experiments, one L. albus and three Andean lupin (L. albus Mihai, L. mutabilis LIB 220, LIB 221, and LIB 222), showed high susceptibility especially for temperatures below $-6^{\circ} \mathrm{C}$ during Phase 1. Severe frost temperatures, below $-8^{\circ} \mathrm{C}$, affected all seedlings. This suggests that a specific cold tolerance threshold could be around $-6{ }^{\circ} \mathrm{C}$, for later development stages. The results indicated that plant growth stage is an important criterion for screening frost tolerant germplasm. Future breeding efforts should be focused on the identification of Andean lupin genotypes with higher stress tolerance and stable yields. This endeavor would stimulate European farmers to cultivate Andean lupin as an alternative to other protein-crops and might also impact positively downstream industries like food, cosmetics, or bioenergy.

Supplementary Materials: The following are available online at https:/ /www.mdpi.com/2077-0 472/11/2/155/s1. Table S1: Descriptive statistical analysis of lupin accessions evaluated using artificial-frost stress and various plant developmental phases. Table S2: Tukey multiple comparison of means at a $95 \%$ family wise confidence level of lupin accession under simulated frost stress.

Author Contributions: Conceptualization, D.P.S., M.v.d.B., and U.P.; methodology, D.P.S., V.S., M.v.d.B., U.P., and I.G.; validation, D.P.S., V.S., and I.G.; formal analysis, D.P.S., V.S., and I.G.; investigation, D.P.S., V.S., D.T., and I.G.; writing—original draft preparation, D.P.S. and I.G.; writingreview and editing, D.P.S., V.S., M.v.d.B., U.P., D.T., P.J.B., and I.G.; visualization, I.G.; supervision, D.P.S. All authors have read and agreed to the published version of the manuscript.

Funding: This research was funded by the Bio-based Industries Joint Undertaking under the European Union's Horizon 2020 research and innovation program, grant agreement No. 720726 (LIBBIO).

Institutional Review Board Statement: Not applicable.

Informed Consent Statement: Not applicable.

Data Availability Statement: Data is contained within the article and supplementary material.

Acknowledgments: The authors would like to thank Instituto Superior de Agronomia (ISA, Lisbon, Portugal) and Vandinter Semo BV, Scheemda, the Netherlands for kindly providing the Lupinus mutabilis seed material used in this study. The authors would like to acknowledge Tudor Aostăcioaei and the research group from the Research Institute for Agriculture and Environment (ICAM), USAMVIasi, Romania for technical support.

Conflicts of Interest: The authors declare no conflict of interest. 


\section{References}

1. Bebeli, P.J.; Lazaridi, E.; Chatzigeorgiou, T.; Suso, M.-J.; Hein, W.; Alexopoulos, A.A.; Canha, G.; van Haren, R.J.F.; Jóhannsson, M.H.; Mateos, C.; et al. State and Progress of Andean Lupin Cultivation in Europe: A Review. Agronomy 2020, 10, 1038. [CrossRef]

2. De Ron, A.; Sparvoli, F.; Pueyo, J.; Bazile, D. Editorial: Protein Crops: Food and Feed for the Future. Front. Plant Sci. 2017, 8. [CrossRef] [PubMed]

3. Gresta, F.; Wink, M.; Prins, U.; Abberton, M.; Capraro, J.; Scarafoni, A.; Hill, G. Lupins in European cropping systems. Legumes Crop. Syst. 2017, CABI, 88-108. [CrossRef]

4. Lucas, M.M.; Stoddard, F.; Annicchiarico, P.; Frias, J.; Martinez-Villaluenga, C.; Sussmann, D.; Duranti, M.; Seger, A.; Zander, P.M.; Pueyo, J.J. The future of lupin as a protein crop in Europe. Front. Plant Sci. 2015, 6. [CrossRef] [PubMed]

5. Gulisano, A.; Alves, S.; Neves Martins, J.; Trindade, L. Genetics and Breeding of Lupinus mutabilis: An Emerging Protein Crop. Front. Plant Sci. 2019, 10, 1385. [CrossRef] [PubMed]

6. Galek, R.; Sawicka-Sienkiewicz, E.; Zalewski, D. Evaluation of interspecific hybrids of andean lupin and their parental forms with regard to some morphological and quantitative characters. Fragm. Agron. (Poland) 2007, 24, 81-87.

7. Hardy, A.; Huyghe, C.; Papineau, J. Dry matter accumulation and partitioning, and seed yield in indeterminate Andean lupin (Lupinus mutabilis Sweet). Aust. J. Agric. Res. 1997, 48, 91-102. [CrossRef]

8. Adhikari, K.N.; Buirchell, B.J.; Sweetingham, M.W. Length of vernalization period affects flowering time in three lupin species. Plant Breed. 2012, 131, 631-636. [CrossRef]

9. Jacobsen, S.-E.; Mujica, A. Geographical distribution of the Andean lupin (Lupinus mutabilis Sweet). Plant Genet. Res. Newslett. 2008, 155, 1-8.

10. R Core Team. R: A Language and Environment for Statistical Computing. R Foundation for Statistical Computing, Vienna, Austria. 2020. Available online: https:/ / www.R-project.org/ (accessed on 10 July 2020).

11. Chalker-Scott, L. Environmental Significance of Anthocyanins in Plant Stress Responses. Photochem. Photobiol. 1999, 70, 1-9. [CrossRef]

12. Hardy, A.; Huyghe, C.; Rahirne, M.A.; Roemer, P.; Neves-Martins, J.M.; Sawieka-Sienkiewiez, E.; Caligarie, P.D.S. Effects of genotype and environment on architecture and flowering time of indeterminate Andean lupins (Lupinus mutabilis Sweet). Aust. J. Agric. Res. 1998, 49, 1241-1251. [CrossRef]

13. Lazaridi, E.; Papadopoulos, G.K.; Bebeli, P.J. Andean Lupin Phenology and Agronomic Performance under Different Planting Dates in a Mediterranean Climate. Agronomy 2020, 10, 2020. [CrossRef]

14. Neves Martins, J.M.; Talhinhas, P.; de Sousa, R.B. Yield and seed chemical composition of Lupinus mutabilis in Portugal. Rev. Ciências Agrárias 2016, 39, 518-525. [CrossRef]

15. Falconi, C.E. Lupinus mutabilis in Ecuador with Special Emphasis on Anthracnose Resistance. Ph.D. Thesis, Wageningen Universi-ty, Wageningen, The Netherlands, 2012.

16. Tang, C.; Robson, A.D.; Longnecker, N.E.; Buirchell, B.J. The Growth of Lupinus Species on Alkaline Soils. Aust. J. Agric. Res. 1995, 46, 255-268. [CrossRef]

17. Kerley, S.J.; Huyghe, C. Comparison of acid and alkaline soil and liquid culture growth systems for studies of shoot and root characteristics of white lupin (Lupinus albus L.) genotypes. Plant Soil 2001, 236, 275-286. [CrossRef]

18. Pszczółkowska, A.; Okorski, A.; Kotecki, A.; Gas, M.; Kullik, T.; Reczek, A. Incidence of seed-borne fungi on Lupinus mutabilis depending on a plant morphotype, sowing date and plant density. J. Elem. 2016, 21, 501-512. [CrossRef]

19. López-Bellido, L.; Fuentes, M.; Lhamby, J.C.B.; Castillo, J.E. Growth and yield of white lupin (Lupinus albus) under Mediterranean conditions: Effect of sowing date. Field Crop. Res. 1994, 36, 87-94. [CrossRef]

20. Raabe, A.; von Sengbusch, R. Zuchterisch wichtige Beobachtungen an einigen Lupinenarten. Der Zuchter 1935, 7, $244-248$. 